\title{
Transatlantica
}

Revue d'études américaines. American Studies Journal

\section{Electricity and Static: Franklin and his British compatriots}

\section{Robert Mankin}

\section{(2) OpenEdition}

1 Journals

\section{Édition électronique}

URL : https://journals.openedition.org/transatlantica/4654

DOI : $10.4000 /$ transatlantica.4654

ISSN : 1765-2766

Éditeur

Association française d'Etudes Américaines (AFEA)

Référence électronique

Robert Mankin, «Electricity and Static: Franklin and his British compatriots », Transatlantica [En ligne], 2| 2009, mis en ligne le 13 janvier 2010, consulté le 04 février 2023. URL : http://

journals.openedition.org/transatlantica/4654; DOI : https://doi.org/10.4000/transatlantica.4654

Ce document a été généré automatiquement le 4 février 2023.

\section{(c) (i) (9)}

Creative Commons - Attribution - Pas d'Utilisation Commerciale - Pas de Modification 4.0 International - CC BY-NC-ND 4.0

https://creativecommons.org/licenses/by-nc-nd/4.0/ 


\title{
Electricity and Static: Franklin and his British compatriots
}

\author{
Robert Mankin
}

\author{
"Why did the English fail to exploit the \\ promising system of their colonial electrician? \\ Obstinacy, obtuseness, complacency, poor \\ judgment, bad luck?"1
}

1 Here is a page from a mid-eighteenth-century journal, an advertizement:
Lecture I
I. Of Electricity in General, giving some Account of the Discovery of it.
II. That the Electric Fire is a Real Element, and different from those heretofore known and named, and collected out of other Matter (not created) by the Friction of Glass, \&c.
III. That it is an extremely subtile Fluid.
IV. That it doth not take up any perceptible Time in passing thro' large Portions of Space.
V. That it is intimately mixed with the Substance of all the other Fluids and Solids of our Globe.
VI. That our Bodies at all Times contain enough of it to set a House on Fire. [...]
$\mathrm{X}$. An artificial Spider, animated by the Electric Fire, so as to act like a live One.
XI. A perpetual Shower of Sand, which rises again as fast as it falls. [...]
XIV. An Appearance like Fishes swimming in the Air.

2 The date is April 1751, the place is Philadelphia, or rather The Pennsylvania Gazette, Philadelphia, in what could still be called "the British Plantations of America". Or is it? From the short passage cited here, the date, to a contemporary Englishman, might easily have been the present-or anywhere from fifty to one hundred years earlier. And the phenomena described might suggest that the writer of these lines was not so much a learned Dissenter as a Puritan enthusiast, taking a private, metaphorical vision for public reality, and ready to redefine the world accordingly. A certain class of Englishmen throughout the eighteenth century, including many we associate with the Enlightenment, feared the return of visionariesthey called them "saints" or simply Puritans ${ }^{3}$-who might want to set the house afire or 
turn the world upside down. Those fishes swimming in the air, a vision of fire as fluid, and showers of sand that rise even as they fall, make a good start; only the word "spirit" seems to be missing. Nor would it have assuaged the apprehensions of many Englishmen if they were told that the lecturer was a Baptist minister, and the concealed author of the program a man who admired the massive gatherings organized in the colonies by his friend the English preacher George Whitefield. It probably would have made them queasier still to be told that the author also believed that matter thought ${ }^{4}$. In the years just after the Jacobite rebellion of 1745, Methodism remained an object of mistrust ${ }^{5}$, and the radical materialism insinuated in the writings of figures like Hobbes, Toland and Collins was still considered dangerous. One proof is that they would soon be decrying it again, when the philosophical works of Bolingbroke were published posthumously in London in 1754.

But of course this is mid-eighteenth-century colonial America and not seventeenth- or eighteenth-century Britain, which helps to underwrite our sense that Benjamin Franklin's rhetoric is not harkening back to the Bible but pointing, in large part, towards prudent natural experiment. Associating colonial America with a more rational attitude towards science will seem paradoxical at the very least, though it would certainly have been auspicious as well. "The British Plantations" would receive a boost by that claim of nature, and the idea that the phenomenon under consideration here is a "general" one, the same in every part of "our Globe". The venerable institutions of European learning would thus have no intrinsic claim to knowledge. Indeed, it was even possible to turn the argument on its head: America was commonly recognized as a more natural setting than Europe, so science may have, or should have, felt more at home in the periphery than in the center, the Old World ${ }^{6}$, and closer to the new land's agenda. Religion would be part of the latter, but in mid-eighteenth-century America, the distinction between Bible and science may have started to look easier to make. With the rise of Evangelical religion, it was being asserted that faith depended on intimate feeling rather than abstract or rational conviction. Perhaps that is why we don't shudder at "an artificial spider, animated by the Electric Fire" or feel we are being told something about ourselves. That image conveys none of the anguish that colonists might have felt in reading a sermon from Connecticut ten years before: "The God that holds you over the pit of hell, much as one holds a spider, or some loathsome insect over the fire, abhors you, and is dreadfully provoked: his wrath towards you burns like fire; he looks upon you as worthy of nothing else, but to be cast into the fire"7. Electric fire was not Calvinistic hell-fire... In addition, this was to be a series of two lectures, not a single rousing sermon or a regular Sunday meeting. So the public is being invited to attend to science-if not in a vacuum, at least in something like a closed circuit. The lectures are recommended to "the cuRIOUs" who will want to know the "curious" (in lower case) experiments that have been "made and published in Europe". The lectures are intellectual but not dangerous, popularizing but still somewhat hierarchical and high-brow. Urbane colonists who can afford the price ${ }^{8}$ will be able to satisfy their curiosity about what the ingenious of America could do with the experiments of the more elitist European virtuosi.

4 We may therefore assume, with a shade too much certainty, that public science is in the offing, a world of "curious" forms of reasoning rather than of threatening politics and religion. That insulated world, or discursive space, was "made in Europe" but could be presented for the edification of interested colonists who know the difference between 
what they feel and what they think, between religion and science. That distinctively American result ${ }^{9}$ may even explain why there has been a scholarly predilection for the subject of Franklin and electricity. Science, divorced from politics and religion, has been a good way to promote one of the great Founding Fathers while affirming at the same time the place of nature in America's national identity. Of course this is not the whole story either: there is also the iconic ubiquity of Franklin flying his kite, one of the founding images of democratic culture. And speaking of which, there is the fun. The lectures turn out to be suitable for those who were curious about more than scientific curiosities. Further points in the program allure with talk of "electrified Money, which scarce any Body will take when offer'd to them" or "Fire darting from a Lady's Lips, so that she may defy any Person to salute her". Step right up, we almost hear, because there turns out, unexpectedly, to be something theatrical in this announcement as well. Anyone needing to slaughter an animal is requested to bring it along for a lethal shock; other paragraphs ("A few Drops of electrified cold Water let fall on a Person's Hand, supplying him with Fire sufficient to kindle a burning Flame with one of the Fingers of his other Hand") sound like pure magic. If utilitarian purposes are being served, the aim is not demystification ${ }^{10}$ but a good time to be had by all. So much for insulation and (one might even think) for the tragic register of history and threats to religious orthodoxy. So much for experiments that can be dignified with the name of Science: at times the rhetoric here is one of circus attractions, entertainment, mere tricks. With that, let us return for a moment to England.

Here is a passage that is related only indirectly to Franklin but that will help us to make out a connection:

Professor Bose, in another Part of his Writings, says, That the Beatification does not always succeed with him; that sometimes, other Circumstances have been very favourable, a Man will be beatified by one Sphere in two Minutes ... That under the same Circumstances, when one Person was capable of being beatified, another was not. ${ }^{11}$

6 These slightly hermetic lines have become familiar but they may still raise eyebrows, and arouse more doubts or worries than a title like "Professor" can allay. Yet they do not even play to our curiosity! As a result, whatever sense of comfort (and dismay) we may be able to derive from seeing Franklin's electric fluid and fire in its American setting, that sense does not cross the ocean very easily, at least towards Britain. There is a problem of jetlag or static. Of course we have lifted the present passage out of context. But what changes when we know that it comes from a report on electricity delivered in a very institutional setting, the Royal Society of London, on 1 March 1749-50? Perhaps we are being reminded, most of all, that as in religion, bad science can lapse into charlatanry, dirty tricks. London's science is beginning to have rules, standards and expectations. In the passage just cited, Professor Bose is actually being berated for negligent reporting: his beatifications do not always work, and others cannot repeat the experiment as he describes it. (He would later confess to having forgotten to mention that the beatifications were carried out on men dressed in suits of armor!) For William Watson F.R.S., the author of this report, Franklin himself was not entirely above suspicion though he had already begun to make a credible appearance on the electric scene in England. ${ }^{12}$ From our vantage, we might want to agree with Watson that something was not altogether clear. To begin with, the lecture outline with which we began advertises that the series will be given by "Mr Kinnersley", though Franklin's autobiography later claimed that the lectures were largely written by 
Franklin himself (LA 1453). Furthermore, for reasons that make his anonymity slightly hard to understand, these "European" discoveries had already been substantially transformed by Franklin's own experiments. Why was he hiding behind the European science? Why was he working through Kinnersley (who was himself a talented student of electricity and a foe of religious enthusiasm)? Or to put the matter differently, apart from the commercial opportunity, why might he have wanted to stand behind the circus décor ${ }^{13}$ This may or may not have been the style in which Franklin himself had been introduced to electricity, via the public lectures of a Scot named Archibald Spencer in Boston in $1743 .{ }^{14}$ That was the same year in which Franklin dreamt of founding the American Philosophical Society. But if he aimed to give science legitimacy in the new world, why was he not introducing a change in 1751 ?

No doubt the answer lies partly in Franklin's growing prominence in public affairs in Pennsylvania, the rapid pace of changes in colonial life, and the difficulty of mixing not only talents, but varied public personae, in the course of a single bustling life. But this paper will argue that the question also has to do with political change, specifically in changing "the British Plantations" into "America", via a claim that (electrical) science can be related to (visionary) demographics. To approach that question, it may be helpful to go back to the jetlag or static that I have been describing. To the extent that Franklin was seeking a place for himself on the European scene in science-and clearly there was no other scene for the time being-"Kinnersley's" circus-like proceedings were not going to be an asset. Yet even "Franklin's" sober scientific activities have something odd-and not simply awkward or provincial-about them. The Preface to Experiments and Observations on Electricity tells the reader the book was published by an editor "without waiting for the ingenious author's permission so to do" and too late for him to make corrections that could appear in the text itself. (They appear in an Appendix instead.) Thus, the first three editions of the work $(1751,1753$, 1760) citeFranklin on the title page but not exactly as the work's author. He is cited instead as an experimenter working "at Philadelphia in America", whose findings are being reported directly to London (where the book was published) and the rest of Europe $^{15}$. Only in 1769 did Franklin unambiguously sign his book, but by then he had also helped to inspire and produce another sort of phantom of his work, in Joseph Priestley's History of Electricity $(1767)^{16}$. The obvious inference from these puzzling details is that when it came to science, Franklin was a man of exemplary prudence, who clung to the role of actor rather than author. Whether his choice makes sense to us or not, Franklin seems to have taken it seriously, and so we should continue to ponder it. No less than British scientists with respect to questions of the church, Franklin managed his career with all the care of a polemical author. But religion was not in any obvious way the issue he was contending with. One proof is the fact that Franklin's strongest influence on British culture was narrowly ${ }^{17}$ confined-to a religious community. But this did not make Franklin associate or identify more clearly with heterodoxy. And even as he gained in fame and popular acclaim, he remained prudent.

With this hasty sketch in mind, I would like to speculate that an idea of politicsAmerican politics-dictated the way that Franklin's science developed. One of the documents said to have launched his interest in electricity is the article from the Gentleman's Magazine of 1745 that Peter Collinson reputedly included along with a Leyden jar in his famous shipment of material to Philadelphia in $1746 .{ }^{18}$ It is possible that the four-page "Historical Account of the wonderful discoveries, made in Germany, 
\&c. concerning Electricity" gave Franklin his first general view of the scientific field; it covers a great deal of ground. And it also contained some suggestive metaphors that were still present in Franklin's mind in 1751. For instance, we here find references to kisses that can be painful and to the experiment of pulling a coin from out of a person's mouth by electricity. Likewise, the question is asked: "Could one believe... that such charming lips could set on fire a house?"19 Beyond these teases, a whole other series of metaphors raise important methodological questions about science. At one point the article urges the experimenter to approach his subject with modesty: "Electricity is a vast country, of which we know only some bordering provinces; it is yet unreasonable to give a map of it, and pretend to assign the laws by which it is governed". The metaphor is in itself commonplace, though it might have struck an American worried in the late 1740's about French expansion in some bordering provinces... However, the reader in 1746 would also have noted that that admirable sense of moderation and restraint gives way by the end of the article, leading to a kind of exultation in scientific progress: "we are in a fair way of soon becoming as well acquainted with that terrible element [electricity], as with air since the invention of the air-pump" (ib., 197). Perhaps the experimenter could hope after all to cross that vast unknown country of a page or two before, and count on making ineluctable progress as he went. This might seem a tendentious reading, but it is supported by the closing paragraph of the "Historical Account":

The study of nature amply recompenses men for their trouble. What astonishing discoveries have been made within these four years! The polypus on one hand, as incredible as a prodigy, and the electric fire on the other, as surprising as a miracle! (idem)

Science is a broad field, including what we would call biology and physical chemistry, living organisms and inanimate matter. A passion for science will lead men deeply and rewardingly into the unknown, an unknown that is neither simply human nor material. Science, in other words, enables men into delve into zones previously reserved for religious usages-mystery, miracle-and underwritten by state governance.

In 1751 Franklin found himself on the verge of a great confrontation, for he seized programmatically on both of the "hands" being brandished in the 1745 conclusion, and his intention was to make them new. Even as he wrote up lectures for Ebenezer Kinnersley, and made some hasty arrangements regarding the publication in London of his Experiments and Observations on electricity, he was also penning a short text entitled "Observations concerning the Increase of Mankind". On the basis of natural conditions prevailing in a "new" country, and with surprisingly little math for a demographic account written in the wake of William Petty, John Graunt and Edmund Halley, the "Observations" came to a radical conclusion. Unlike European societies, which were calculated to double in size every 360 years, an expanding agrarian society like America could reasonably be expected to double every twenty years. This kind of growth could not even be instanced in that monstrous exceptional thing, a city ${ }^{20}$, much less in a country or a land mass. To recap his surprising argument about natural populousness, one may think that Franklin looked for an example and hit upon two. The first was vegetable: the fennel plant, if given the chance to spread, will overrun the land. The second was animal-or more: a mysterious creature that had intrigued scientists in France and at the Royal Society in recent years, the polypus. The scientific discussion of the $1740^{\prime} \mathrm{s}^{21}$ could not exclude the possibility that that spidery looking creature was in fact a kind of incomprehensible matter and not an animate being at all. 
As if the fennel was nature and the polypus was science! In any case, Franklin was insisting that science and nature could be used to expound politics:

In fine, A Nation well regulated is like a Polypus; take away a Limb, its Place is soon supply'd; cut it in two, and each deficient Part shall speedily grow out of the Part remaining. Thus if you have Room and Subsistence enough, as you may by dividing, make ten Polypes out of one, you may of one make ten Nations, equally populous and powerful; or rather, increase a Nation ten fold in Numbers and Strength (\$23).

Franklin's article was published for the first time in 1755 (once again, anonymously) and regularly reprinted in the years that followed. It is not too much to say it sent a ripple, or even an electroshock, through British culture. For Franklin's eye-opening realization was that in one hundred years time, the colonies would be more populous than the mother country and so the future of Britain would lie in America. What is more, Franklin specifically closed the door to the colonies becoming the present United States, i.e. by accepting immigrant populations of many different origins. The paragraph just cited goes on, in conclusion to the Observations, to object on racial and ethnic grounds to the arrival of other than British settlers in the future. Franklin would one day be a separatist, but in 1751, he was insisting-in very offensive termsthat Britain's future must be America. The terms were so offensive, to Germans among others, that reprintings of the article often deleted the last paragraph and thus ended with the passage I have cited ${ }^{22}$.

The key argument about America's polypus growth and extraordinary future remained, and it would be my contention in a larger study that Franklin's 1751 claims had explicit effects on the shape of intellectual life in Britain in the decades that followed, as seen in the works of Josiah Tucker and Adam Smith. For now, it will be enough to point to a slight, but symptomatic example. It involves a surprising revision that David Hume made in his History of Great Britain (1754) when he produced a second edition of the work in 1759. There are good reasons to believe Hume had become attentive to Franklin's work though he had yet to meet him in person: if nothing else, Franklin was in London from 1757 through 1762, and during that time he became close to Hume's publisher and friend William Strahan, among many others. Hume would later seek out Franklin's company and even host him in his apartments in Edinburgh ${ }^{23}$. But in 1758, even as Franklin was performing electrical demonstrations at Cambridge University, and being touted there, Hume saw fit to make a surprising change in a passage he had written in his History about the settlement of the American continent. Here is the 1754 original:

Peopled gradually from England by the necessitous and indigent, who, at home, encreased neither wealth nor populousness, the colonies, which were planted along that tract, have promoted the navigation, encouraged the industry, and even perhaps multiplied the inhabitants of their mother-country. The spirit of independency, which was reviving in England, here shone forth in its full lustre, and received new accession of force from the aspiring character of those, who, being discontented with the established church and monarchy, had sought for freedom amidst those savage desarts. The seeds of many a noble state have been sown in climates, kept desolate by the wild manners of the antient inhabitants; and as asylum secured, in that solitary world, for liberty and science, if ever the spreading of unlimited empire, or the inroad of barbarous nations, should again extinguish them in this turbulent and restless hemisphere. ${ }^{24}$ population and given the subject (the development of the colonies from the time of 
James I in particular) it is hardly surprising that he has recourse to some of the same themes. One might even adduce as proof that the two accounts are distinct and even mutually repellent, the rather unexpected fact that for Hume the mother (-country) grows because her child grows. Franklin recognized the possibility of mutual development but because of the geography insisted on natural, generational change, from old to new: the Observations proclaim that a decisive demographic shift is underway. What is more, Franklin's whole account is based on the idea that nations can be 'full settled' ( $\$ 4, \S 5$, etc.) and then superseded. But our imagination of repulsion also makes it easy to imagine attraction, so that by 1766 we may well feel that Hume had embraced Franklin's vision, and perhaps even its cultural biases. For in that year he exhorted the young Edward Gibbon, who had begun his history-writing career in French, to return to his native language:

Let the French [...] triumph in the present diffusion of their tongue. Our solid and increasing establishments in America, where we need less dread the inundation of Barbarians, promise a superior stability and duration to the English language..$^{25}$

In this arresting remark, England or Britain is not over and done with, but French is. One can hardly deny that Hume's recourse to a linguistic version of Franklin's account was equally prophetic ${ }^{26}$.

Given this formulation, and the way it implies some measure of agreement between Hume and Franklin, it is all the more surprising that in the revisions to his History (made in the summer of $1758^{27}$ ) Hume removed the final sentence of the passage I have cited, from "The seeds" to "hemisphere". European "liberty and science" apparently would not find their home in America in the way that Hume had been capable of imagining five years earlier. Again, there is no absolutely compelling reason to connect this statement or its removal with Franklin, but clearly there was no figure in public life so capable of uniting those two values in connection with the British colonies in America. The obvious reason for Hume's reluctance to keep the statement (apart from some uncharacteristically obscure grammar) was the world war we know as the Seven Years' War, which had begun in 1756. European turbulence and restlessness were pouring onto new continents, and without the positive connotations (à la Montesquieu) of liberty necessarily being associated with those terms. One might also imagine that for a man like Hume, who was denied a place in the Scottish university of the eighteenth century because of his religious scepticism, Franklin's almost instant stardom at Cambridge and Saint Andrews (where he was made an honorary doctor in February 1759) proved that radical beliefs in one world were not radical in the same ways in the other. So European or British liberty, assuming they were not indigent, and the British "science of man" that Hume himself had hoped to found, were perhaps not going to survive so easily in their European forms once transported across the ocean. In the best-case scenario, the new world of communication in the English language would put readers everywhere on a par and enable them to debate. But it was also possible Hume had understood that the new world was changing and electrifying old Europe's relation to its own history. Europe may be an overstatement in this context, for in 18thcentury France, an evolution similar to what Franklin hoped for may have been underway. According to one account, which hardly rejoiced in the fact, science was becoming an expression of the "nation", at every level of French society ${ }^{28}$. Franklin certainly knew of this, and developments in France have their part in the shaping of his vision of America. But to return to Britain and what were still its colonies, it would be wrong to think that a social response to these developments was lacking: to the polypus 
growth of nature and of men who refuse to stay in their place as laborers, Britain soon opposed a science of social interdependence and specialized functions that today we call economics, and a vision of human becoming associated with civil society. In that sense, it may be argued that the polymath Franklin turned America away from a British Enlightenment he helped to stimulate, in order to make it the land of nature and science.

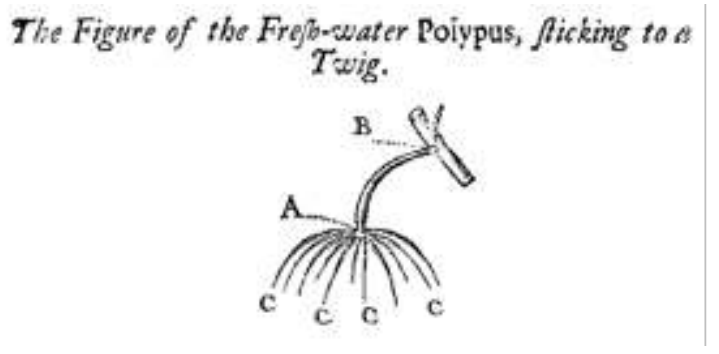

\section{BIBLIOGRAPHIE}

Illustration from "Observations and Experiments upon the Freshwater Polypus, by Monsieur Trembley". Philosophical Transactions of the Royal Society, vol. 42, 1 January 1742, p. iii.

ADDISON, Joseph \& Richard STEELE, The Tatler, ed. Donald F. Bond (Oxford: Clarendon Press, 1987), 3 vols.

Anon., "Historical Account of the wonderful discoveries, made in Germany, \&c. concerning Electricity”. TheGentleman's Magazine, April 1745, p. 193-7.

Anon., « Réflexions générales sur l'utilité des Belles-Lettres, et sur les inconvéniens du goût exclusif, qui paroît s'établir en faveur des Mathématiques \& de la Physique », Histoire de I'Académie des Inscriptions et des Belles-Lettres, XVI, 1751), p. 11-37.

Anon. [Benjamin Franklin], "Extract from a piece written in Pensylvania in 1751, entitled, Observations concerning the Increase of Mankind, Peopling of Countries, \&c.", Annual Register for 1760 (London: Dodsley, 1761), p. 191-196.

BARROUX, Gilles, « Lorsque Tremblay et Réaumur parlaient de "régénération" ». Médecine/ Sciences 2003: 19, 761-762. http://ist.inserm.fr/basismedsci/2003/

ms_6-7_2003/761_Barroux_PH.pdf

CHAPLIN, Joyce, The First Scientific American. Benjamin Franklin and the Pursuit of Genius (New York: Basic Books, 2006).

CLARK, J.C.D., The Language of Liberty, 1660-1832. Political Discourse and Social Dynamics in the AngloAmerican World (Cambridge: CUP, 1994).

COHEN, I. Bernard, Benjamin Franklin's Science (Cambridge: Harvard UP, 1990).

DELBOURGO, James, "The Electric Machine in the American Garden" in Science and Empire in the Atlantic World, ed. James Delbourgo and Nicholas Dew (New York \& Abingdon: Routledge, 2008), p. 255-280. 
EDWARDS, Jonathan, "Sinners in the Hands of an Angry God" in Basic Writings, ed. Ola Elizabeth Winslow (New York: New American Library, 1966), p. 150-168.

FRANKLIN, Benjamin, Experiments and Observations on Electricity, made at Philadelphia in America, by Mr Benjamin Franklin. (London: Cave, 1751, 1753, 1760).

--- Writings (New York: Library of America, 1987).

--- The Papers of Benjamin Franklin.http://franklinpapers.org/franklin/

GIBBON, Edward, The Letters of Edward Gibbon, ed. J.E. Norton (London: Cassell, 1956), 3 vols.

HEILBRON, J.L., Electricity in the $17^{\text {th }}$ and $18^{\text {th }}$ Centuries. A Study of Early Modern Physics (Berkeley: University of California Press, 1979).

--- "Franklin, Haller and Franklinist History." Isis 68 (24), 1977, p. 539-49.

HUME, David, The History of Great Britain (Edinburgh: Hamilton, Balfour \& Neill, 1754)

--- idem, $2^{\text {nd }}$ ed. (London: Millar, 1759).

--- The Letters of David Hume, ed. J.Y.T. Greig (Oxford: Clarendon Press, 1932).

LOCKE, John, Two Treatises of Government, ed. Peter Laslett (Cambridge: Cambridge University Press, student edition 1988).

NOLLET, Jean-Antoine and William WATSON, “An Account of a Treatise, presented to the Royal Society, intituled, Letters concerning Electricity, in which the latest Discoveries upon this Subject, and the Consequences which may be deduced from them, are examined; by the Abbé Nollet...", Philosophical Transactions of the Royal Society, vol. 48, 17 May 1753, p. 201-216.

TREMBLEY, A., "Observations and Experiments upon the Freshwater Polypus, by Monsieur Trembley". Philosophical Transactions of the Royal Society, vol. 42, 1 January 1742, p. iiixi.

WATSON, William, “A Letter from Mr William Watson, F.R.S. to the Royal Society, declaring that he as well as many others have not been able to make Odours pass thro' Gas by means of Electricity...". Philosophical Transactions of the Royal Society, vol. 46, 1 March 1749-1750, p. 348-356.

\section{NOTES}

1. J.L. Heilbron, Electricity in the $17^{\text {th }}$ and $18^{\text {th }}$ Centuries. A Study of Early Modern Physics (Berkeley: University of California Press, 1979), p. 346.

2. Benjamin Franklin, Writings (New York: Library of America [LA], 1987), p. 355-7. Franklin's original project for the American Philosophical Society, in 1743, called for the founding of a society "for promoting useful knowledge among the British plantations in America". The project did not take on its definitive name before 1766.

3. Edward Gibbon's fright at the Gordon Riots recurred to this language, as if automatically: "As a M.[ember] of $\mathrm{P}$ [arliament], I cannot be exposed to any danger as the $\mathrm{H}$ [ouse] of C[ommons] has adjourned to Monday sennight: as an individual I do not conceive myself to be obnoxious. I am apt without duty or necessity to thrust myself into a Mob: and our part of the town is as quiet as a Country Village. So much for personal safety: but I cannot give the same assurances of public tranquillity: forty thousand Puritans such as they might be in the time of Cromwell have started out of their graves, the tumult has been dreadful." The Letters of Edward Gibbon, ed. J.E. 
Norton (London: Cassell, 1956), 3 vols., ii.243; to Dorothea Gibbon, 8 June 1780. This reflex probably waned in the 1780 's, to be replaced by the conviction that Dissenters and revolutionaries were atheists.

4. To [Thomas Hopkinson?], 16 October 1746. Except when the LA volume is specifically mentioned, my references are taken from the material available online at the Franklin Papers website:http://franklinpapers.org/franklin/

5. In Philadelphia, Whitefield made his anti-Jacobite stance clear and Franklin was careful to report it. "Extract from The Pennsylvania Gazette", 28 August 1746.

6. Franklin speaks of rural Europe as "old countries" (LA 367). And the newness and natural condition of America was memorably formulated by Locke: "In the Beginning, all the World was America" (Two Treatises of Government, 1690, II.49). But most of the rest of the world, for Locke, had since been subjected to appropriation of common lands, political organization and history.

7. Jonathan Edwards, "Sinners in the Hands of an Angry God", 8 July 1741 in Basic Writings, ed. Ola Elizabeth Winslow (New York: New American Library, 1966), p. 150-168.

8. It may have been steep: "seven Shillings and Six-pence for each Person to go thro' the Course" (AL, 357). In the same year (1751) Franklin's book on electricity was being sold to a specialized audience for $2 \mathrm{~s} 6 \mathrm{~d}$ (as announced by its London publisher). Currency circulating in the colonies had roughly half the value of sterling.

9. Or so it was (January 2008). For a cogent and knowledgeable account that takes a more positive view, see James Delbourgo, "The Electric Machine in the American Garden" in Science and Empire in the Atlantic World, ed. James Delbourgo and Nicholas Dew (New York \& Abingdon: Routledge, 2008), p. 255-280.

10. No. 21 of Steele's "Tatler", dated 28 May 1709, turns a report of witchcraft into a matter of common sense, e.g. when a 'hag' practicing voodoo turns out to be baking gingerbread. The mystery is not alleviated in Franklin's show, nor ultimately in Addison and Steele's. The Tatler and Spectator were powerful influences on his career as a writer.

11. "A Letter from Mr William Watson, F.R.S. to the Royal Society, declaring that he as well as many others have not been able...", p. 351.

12. Idem, p. 354-5; Watson's report to the RS on Nollet's letters on electricity, dated 17 May 1753, suggests that Nollet and not Franklin may have performed experiments associated with Franklin most of all. Cf. "An Account of a Treatise, presented to the Royal Society, intituled, Letters concerning Electricity, in which the latest Discoveries upon this Subject, and the Consequences which may be deduced from them, are examined; by the Abbé Nollet...", p. 204.

13. In this setting and elsewhere in the subjects of the present paper, it seems difficult to accept Joyce Chaplin's vision of Franklin as perpetually "work[ing] his way to center stage". Cf. The First Scientific American. Benjamin Franklin and the Pursuit of Genius (New York: Basic Books, 2006), p. 132.

14. In Benjamin Franklin's Science (Cambridge: Harvard UP, 1990), p. 44-7, I. Bernard Cohen reproduces the probable contents of Spencer's lectures, which in all sound less entertaining. Previous scholarly accounts of Spencer made him out to be more of a showman. Cohen also establishes the dates for Franklin's viewing of Spencer's lectures, which do not correspond exactly to Franklin's recollections of "Dr Spence" in the Autobiography (LA 1452-3).

15. Cohen (op. cit., p. 224, n. 1) makes the extraordinary point that the Experiments had never been published as a separate volume in America before his edition of 1941. Yet as "one of the most widely reprinted scientific treatises of the Enlightenment", there had been "five editions in English, three in French (in two different translations), and one each in German, Italian and Latin" (p. 28, 222 n. 56), presumably during Franklin's lifetime. It is astonishing and suggestive that Franklin, a printer, never produced the book in America. 
16. J.L. Heilbron aptly casts Priestley's book as "the fountainhead of Franklinist historiography". Cf. "Franklin, Haller and Franklinist History”. Isis 68 (24), 1977, p. 539-49.

17. Heilbron (Electricity in the $17^{\text {th }}$ and $18^{\text {th }}$ Centuries, p. 345) speaks of England's "benign indifference" to Franklin's discoveries. The Dissenters frequented by Franklin were active in science, radical in politics, and remarkably undecisive in the effects they produced on the mind of eighteenth-century Britain... For a portrait of the Dissenting community, see J.C.D. Clark, The Language of Liberty, 1660-1832. Political Discourse and Social Dynamics in the Anglo-American World (Cambridge: CUP, 1994), p. 328f. et passim.

18. Cf. Franklin to Michael Collinson, 8 February 1770. The complicated history of the article is explored in almost full detail in Heilbron's Electricity in the $17^{\text {th }}$ and $18^{\text {th }}$ Centuries, op. cit., p. 324-5, and in his article in Isis.

19. Gentleman's Magazine, April 1745, p. 193-7; here p. 194.

20. David Hume could associate substantial growth only with London, though he did so via a dialectic between city and country. In the course of his history of Britain, he cites population estimates for England in 1583 and immediately observes: "It is impossible to warrant the exactness of this computation; or rather, we may fairly presume it to be somewhat inaccurate. But, if it approached near the truth, England has probably, since that time, increased much in populousness. The growth of London, in riches and beauty, as well as numbers of inhabitants, has been prodigious. From 1600, it doubled every forty years [here a reference to Petty]; and consequently in 1680, it contained four times as many inhabitants, as at the beginning of the century. It has ever been the center of all the trade in the kingdom; and almost the only town which affords society and amusement. The affection, which the English bear to a country life, makes the provincial towns be little frequented by the gentry. Nothing but the allurements of the capital, which is favored by the residence of the king, by being the seat of government, and of all the courts of law, can prevail over their passion for their rural villas." History of Great Britain (Edinburgh: Hamilton, Balfour \& Neill, 1754) p. 129.

21. The mysteries of the polypus are put in a modern perspective by Gilles Barroux in « Lorsque Tremblay et Réaumur parlaient de "régénération" ». Médecine/Sciences 2003: 19, 761-762. Accessed (January 2008) at http://ist.inserm.fr/basismedsci/2003/ ms_6-7_2003/761_Barroux_PH.pdf

22. This was the case even in Britain: the Annual Register for 1760 replaces the ending of the text, which it otherwise reprints in full, with asterisks.

23. In January 1760 Franklin wrote flatteringly to adopt Scotland as almost his second patria: "I think the Time we spent [in Scotland], was Six Weeks of the densest Happiness I have met with in any Part of my Life. And the agreable and instructive Society we found there in such Plenty, has left so pleasing an Impression on my Memory, that did not strong Connections draw me elsewhere, I believe Scotland would be the Country I should chuse to spend the Remainder of my Days in" (To Lord Kames, 3 January 1760; Franklin's emphasis).

24. Hume, The History of Great Britain (1754 ed.), p. 134. The corresponding passage appears at p. 124 of the 1759 edition.

25. To Edward Gibbon, 24 October 1766, in The Letters of David Hume, ed. J.Y.T. Greig (Oxford: Clarendon Press, 1932), 2 vols., ii.171. Hume may even be echoing Franklin's language in a letter of 3 January 1760 to Lord Kames: "No one can rejoice more sincerely than I do on the Reduction of Canada; and this, not merely as I am a Colonist, but as I am a Briton. I have long been of Opinion, that the Foundations of the future Grandeur and Stability of the British Empire, lie in America; and tho', like other Foundations, they are low and little seen, they are nevertheless, broad and Strong enough to support the greatest Political Structure Human Wisdom ever yet erected." Hume and Kames were still fairly close at the time.

26. Cp. Franklin's remarks on the subject to Collinson, in a letter dated 9 May 1753.

27. Letters of David Hume, i.280-1. 
28. A 1751 meditation on science and letters argues that thanks to the publications of the Académie des Sciences, "les Sciences qu'on nomme Exactes" have been "insensiblement amenées au point d'être chez nous le goût dominant, ou plutôt un goût national, commun à toutes les conditions \& à tous les états, sans excepter même cette moitié de la société, qui, contente autrefois des avantages qu'elle tient de la Nature, n'envioit point à l'autre ceux qu'on ne peut acquérir que par une étude pénible". And the sciences have been changed in the process: certain of them "ont le privilège d'attacher tout à la fois l'esprit \& les yeux, par des spectacles, qui, sans cesser d'être aussi agréables que s'ils étoient frivoles, conservent le mérite de paroître liés à une profonde théorie. Des observations amusantes, des expériences singulières, une machine ingénieuse, sont à la portée de tout le monde". See the anonymous "Réflexions générales sur l'utilité des Belles-Lettres et sur les inconvéniens du goût exclusif, qui paroît s'établir en faveur des Mathématiques \& de la Physique", Histoire de l'Académie des Inscriptions et des Belles-Lettres, xvi (1751), p. 15, 17.

\section{RÉSUMÉS}

Les découvertes en électricité de Benjamin Franklin ont mobilisé des chercheurs depuis des décennies. Cet essai ne traite pas de ces découvertes au sens strict, mais étudie le contexte dans lequel Franklin a présenté certains de ses travaux scientifiques et politiques en 1751, ainsi que leur réception en Grande-Bretagne. L'essai suggère que Franklin ne fut ni l'enfant des Lumières britanniques ou européennes, ni un de leurs jouets. Bien que célébré très généralement par son siècle, Franklin demeurait comme une force étrangère à laquelle les Lumières britanniques devaient faire face, tant sur le plan intellectuel que politique. Peut-être que cette situation explique pourquoi il fut un adversaire si redoutable pour l'Etat britannique.

Franklin's discoveries in electricity have rewarded scholarly attention for many decades. This short essay is not about electricity in the strict sense, but about the context in which Franklin presented some of his work in science and in politics in 1751, and about the way that work was received in Britain. The aim of the essay is to suggest that Franklin was neither a child of the British or European Enlightenment nor one of its toys. And though he may have been touted very generally as an inspiration, he was closer to a foreign force with which, intellectually as well as a politically, it had to contend. This may help in explaining why he proved so considerable a foe to the British state.

\section{INDEX}

Mots-clés : démographie, électricité, Franklin Benjamin, Hume David, politique, science

Keywords : demographics, electricity, Franklin Benjamin, Hume David, politics, science

\section{AUTEUR}

\section{ROBERT MANKIN}

Professeur de civilisation britannique, Université Paris-Diderot, mankin@univ-paris-diderot.fr 